\title{
SYNCHRONIZATION OF DUAL SYSTEM EDUCATION PROGRAMS IN VOCATIONAL SCHOOLS WITH WORK NEEDS
}

\author{
Yeni Fitriana $^{\text {a* }}$, Sugiyono ${ }^{b}$ \\ $\mathrm{a}^{*}$ Post Graduate School, \\ Yogyakarta State University \\ Jl. Colombo No.1, Sleman District, Yogyakarta, Indonesia. jenny.86291@gmail.com \\ ${ }^{\mathrm{b}}$ Lecturer, \\ Yogyakarta State University \\ J1. Colombo No.1, Sleman District, Yogyakarta, Indonesia. sugiyono_1953@yahoo.com
}

\begin{abstract}
This paper was written with the aim of providing insight into the synchronization of the Dual System Education (DSE) program in Vocational Schools with work requirements. Dual System Education (DSE) is a form of providing vocational expertise education and training that integrates systematically and synchronously between school education programs and work mastery programs, which aim to; produce workforce that has professional expertise, improve and strengthen link and match between vocational and world education institutions, improve the efficiency of the education process and training professional-quality workforce, and provide recognition and appreciation of work experience as part of the education process. The partnership between educational institutions and the business world/industry is the key to the success of Dual System Education (DSE) in Vocational Schools, where education is designed, implemented and evaluated together.
\end{abstract}

Keywords: DSE, link and match, Synchronization, Vocational School.

Received: 15 Oct 2019 - Revised: 20 Nov 2019 -Accepted 15 Dec 2019 - Available online 30 Dec 2019

\section{INTRODUCTION}

talking about the need for human resources, of course, is closely related to the existence of middle-level skilled workers who are needed in the industrial era in the future. In the Law No. 29 of 1990 article 2 paragraph 2 explicitly stated that vocational secondary education prioritizes the preparation of students to enter employment and develop student professionalism.

Vocational education, which provides individuals with knowledge, skills and competencies and enhances their abilities in various ways, prioritizes qualitative functions and strengths in accordance with the country's economic situation. Therefore, the reason for vocational education is the labor market, and its main purpose is to meet the demands of the business and labor force. Vocational education includes skills or expertise, knowledge and mental attitude. Thus vocational education is intended as a special education that aims to prepare individuals to enter a particular workforce. This goal does not conflict with the political attitudes of vocational education, on the contrary, the general goal is supported by the community. In this case, vocational and technical education is a process to educate individuals for knowledge, skills and behavior for certain types of professions and to enable individuals to be financially and socially strong in social life. It intends to prepare them for industry, agriculture, trade and other regional services. 
The role of a qualified workforce that requires individuals to have knowledge, skills and competencies is very important because they are a key element for the industrialization and development of the country. Vocational and technical education is a type of training that systematically supports individuals with knowledge, skills and competencies for areas whose work is needed in every aspect of social life.

In connection with the strategy of developing education in the country, one terminology has emerged, namely the concept of link and match. This concept is simply interpreted as an effort to direct educational institutions to issue outputs that are not merely a place to develop their abilities and expertise but can meet the needs of the community.

The link and match between educational programs in schools with the needs of the community is questioned again especially in the development of vocational secondary education. Seen from a number of studies, vocational education programs are currently less related and less in line with employment needs in industry. Vocational High Schools aim not only to create job seekers from existing jobs, but are also expected to be active and creative in opening or creating new jobs.

The real impact of the Dual System Education is the role of the business world and the industrial world on the education system, the tendency to compile and implement curriculum and subject matter in schools to suit the needs of the business world or the industrial world. This is often interpreted as refraction of the education function, namely so that the educational objectives can direct students to have readiness to work. The business world and the industrial world want an educational method that allows graduates of vocational schools to become workers who are ready to use.

Based on the description above the authors intend to explain the study of synchronizing the Dual System Education program in Vocational Schools with work needs. This paper aims to explain a number of things regarding the achievement of indicators of the relevance of Dual System Education to the world of work.

\section{METHODS}

This paper is a literature review using a descriptive approach. Descriptive research aims to systematically and accurately describe facts and characteristics about an event or regarding a particular field. This study tries to describe a situation or event. This literature review aims to build and construct a stronger conception based on empirical studies conducted. In this study, researchers mapped a number of articles or studies relating to vocational schools, Dual Systems Education, and the concept of link and match. Furthermore, specifically, the author examines empirical articles relating to the relationship of Dual System Education with work needs through the concept of link and match.

\section{RESULTS AND DISCUSSION}

\section{A. Dual System Education and Vocational Schools}

Dual System Education is a form of organizing vocational education and training that combines systematically and synchronously between education programs in schools and work mastery programs. Thus the vocational students with this dual system education program will have a professional level that is connected with the world of work needed. At school students learn with teachers and are generally funded by the government while in companies generally they train with instructors in the company and are funded by the company.

According to (Djati, 2001) explained that Dual System Education is an implementation of the concept of link and match, namely curriculum design, learning process, and the implementation of evaluation is designed and implemented jointly by the school and industry. This system is a form of organizing education and vocational skills training that systematically and synchronizes the education program in schools and the mastery of expertise programs obtained through direct practice and the world of work. 
In this sense, it means that there are two parties, namely educational institutions (training) in schools and employment (industry/companies) which jointly organize a vocational education and training program. Both parties really process in it with all the advantages and disadvantages of each.

The implementation of dual system education in general aims to answer the challenges of the industry. But according to (Djati, 2001) Dual System Education aims, first, to produce workers who have professional expertise, namely workers who have a level of ability, competence, and work ethic in accordance with the demands of employment. Second, improve and strengthen the link and match between vocational education and training institutions and the world of work. Third, improve the efficiency of the education process and training of professionally qualified workforce. Fourth, give recognition and respect for work experience as part of the education process. (Gelisi, 2016) Shows the main objective of the dual education system is to provide students with extensive knowledge and skills for their future careers according to changing needs of the business world.

Dual system education requires the existence of other institutions so that there is cooperation and agreement between vocational education institutions (SMK) and other institutions (industry / companies or other institutions related to employment) that have the resources to develop vocational skills to jointly organize education and vocational skills training. Other institutions are called Partner Institutions, which are institutions that engage themselves in collaboration with vocational education institutions (SMK).

(Geneva, 2000) Defines vocational education as a function of vocational education to prepare a foundation and special skills for a person, develop them to get a job, help them work productively and adaptively in conditions and tasks with different technologies.

The curriculum has been compiled in a Vocational School environment to become a joint program of schools and industry, it is necessary to make adjustments or synchronization between the material contained in the curriculum with the fields of work available at IP that can be used as a vehicle for learning for students in achieving mastery of the required skills. The synchronization must be carried out together and the results are an education and training program agreed by both parties to be carried out together in a consistent manner.

Evidence from cross-country comparisons in Europe, which has sought to implement a vocational school system, shows the need for some systematic elements to ensure success, as explained below:

1.Ensure curriculum relevance: All stakeholders (government, employers, social partners, educational institutions) need to be involved in curriculum development, with clear assignments of responsibilities. The weight of each sound may vary by country.

2. Maintain close labor market contacts: A continuous feedback system from employers and private sector institutions makes it possible to adapt training content to the needs of the labor market. This element requires the involvement of entrepreneurs at a high level.

3. Ensure high-quality training: Sufficient funds are needed to guarantee suitable teaching materials and the availability of trained teachers. A decentralized system of quality assurance and local competition among training centers, combined with output-based funding and licensing, needs to be established.

4. Establish a qualification framework: Centralized accreditation of the training curriculum creates transparency and encourages acceptance among employers.

Limit the risk of creating a dead-end vocational school path: Competencies and qualifications obtained must be comparable and can be credited with academic qualifications to promote transfer-ability between the two and to 


\section{Yeni Fitriana, et al. /Journal of Educational Administration Research and Review / \\ Vol. 3 No. 2 December 2019}

avoid stigmatization of vocational school participants.

In the first decade of international development cooperation, Dual Systems Education was one of the main education sub-sectors that was invested together with tertiary education. In the 1960s and 1970s, the World Bank provided about $40 \%$ of all education loans in SubSaharan Africa for Dual Systems Education (Tikly, 2013). Dual System Education in Vocational Schools is considered as the main component of labor forecasting to serve the needs of industrialization (Heyneman, 2003). UNESCO's focus is on basic education (Chabbott, 2003), which is the basic education sector, but it also contains many components of skills development, as well as its functional literacy policy in the future. A number of bilateral donors, mainly but not exclusively German-speaking, support the Dual System of Vocational Education as a priority sector.

Thus the Dual System Education is directed to produce graduates who have certain professional expertise in a standard manner according to the needs of the job market. Therefore, everything related to planning, organizing and evaluating education and training must always refer to the achievement of professional ability standards in accordance with the demands of certain job titles or professions that apply in the workforce. For this reason, every education and training program must contain professional standards that clearly contain a measure of ability and at the same time describe the authority to carry out certain professional tasks.

\section{B. Link and Match Policy}

nly but not exclusively German-speaking, support the Dual System of Vocational Education as a priority sector.

One of the government's policies to succeed the SMK Revitalization program is Regulation of the Minister of Industry (Permenperin) No. 3 of 2017. Philosophically, link and match implies insight into human resource development, the future, quality and excellence, professionalism, added value and efficiency. Link and match involves an interactive process with appropriate results (Djojonegoro, 2010). Theoretically, link and match refers to the link and match the competence of graduates from the world of education in order to be accepted and match the needs of the workforce. Another opinion states that link and match is exploring the competencies needed by the job market going forward. It is hoped that the educational orientation paradigm will no longer be supply minded but rather demand minded (market needs). The link and match program includes two targets, namely at the secondary school level, and at the tertiary level (Soesilowati, 2009). From this statement, it can be seen that the education world should be able to establish cooperation with all parties related to the world of work, such as industry.

The business world or industry has a very strategic role in the implementation of Dual System Education, namely: (1) As an equal partner, in the implementation of Dual System Education the world of work has the same role and function as the school, the role of this partnership can be realized from the availability of the world of work becoming a partner institution, (2) Responsible, this implies that the world of work has the same responsibilities as the world of education, (3) Promoters, the world of work acts as a promoter that promotes the quality of graduates of skilled labor and the quality of schools as human resources, providers workforce in accordance with the needs of the job market, (4) Inspiratory, the world of work acts as an inspiratory who inspires the principal to immediately conduct improvisations in teaching and learning activities to be in line with developments available in the world of work, (5) Motivators, the world of work acting as a motivator that drives schools so that do more in improving the work ethic, discipline of Vocational High School graduates, (6) Communicators, the world of work which has become a partner institution acts as a communicator who communicates the existence and potential of the school and the quality of graduates to companies that join in an association or other company outside of its association (7) Facilitator, the world of work 


\section{Yeni Fitriana, et al. /Journal of Educational Administration Research and Review / \\ Vol. 3 No. 2 December 2019}

which has become a partner institution is willing to provide facilities for the productive skills practice of vocational school graduates and, if possible, provide equipment for basic practice facilities / advanced practice in schools.

Management of Dual System Education must be in accordance with the Link and Match policy, so that Ga System Education can run according to the procedure. There are several paradigm changes and dimensions of renewal that are derived from the link and match policy (Djati, 2001), namely:

1. Change from the Supply Driven approach to Demand Driven

2. Change from school-based education (School Based Program) to dual-based system (Dual Based Program)

3. Changes from teaching models that teach subjects to competency-based teaching models

4. The change from a narrow basic program (Narrow Based) to a basic program that is basic, strong and broad (Broad Based)

5. Change from a rigid formal education system, to a flexible system and adheres to the principle of multi entry, multi exit

6. A change from a system that does not recognize previously acquired expertise, to a system that recognizes the expertise gained from where and in whatever way the competency is obtained (Recognition of prior learning)

7. Change from the separation between education and vocational training, into a new system that integrates vocational education and training in an integrated manner

8. Change from the terminal system to a continuous system

9. Change from centralized management to independent management patterns (the principle of decentralization)

The change from a complete dependency from central government financing, to self-financing with central government subsidies
Then (Listiana, 2012) states that there are several principles of link and match policy in dual system education, namely:

1. Improvement of Facilities and Infrastructure The education curriculum must be prepared taking into account the progress of science and technology developing in the community, meaning that educational institutions are required to get closer to the industrial world in order to develop curriculum that is tailored to the needs of the community.

2. Improvement of Facilities and Infrastructure Adequate facilities and infrastructure are needed to support the implementation of research in industry and other practices, so that efforts to increase the relevance of educational programs to the needs of the community can be realized so that it will be easier to implement a link and match policy.

3. Improving the Quality of Teachers

Teachers must be able to compete with workers in the world of work. In addition, there is a need for flexibility of teaching staff who can be assigned at any time to work in the industrial field and vice versa industrial workers are given the opportunity to serve in the world of education within a certain time.

\section{Improvement of Education Programs}

The intended program is a program that leads to the needs of the community with the aim of creating relevance between the educational program and the needs of the community. With the relevance of the education program it is hoped that the link and match policy can be implemented well.

To create quality SMKs, it is necessary to implement a link and match between schools and industries in a gradual and continuous manner in the form of collaborative research and research. There are several parties that are interrelated to realize this link and match program, including vocational education, the industrial world, and the government. 


\section{Yeni Fitriana, et al. /Journal of Educational Administration Research and Review / \\ Vol. 3 No. 2 December 2019}

\section{Synchronization of Dual Education Systems for the World of Work}

Learning materials provided in schools are basic theoretical provisions and basic vocational skills. While in the industry or institution the pair of students learn real work knowledge and skills as well as work attitudes and responsibilities towards work results. Thus logically students who carry out dual system education have abilities that are more relevant to the needs of the job market. Vocational schools in the regions need to pay attention to the achievement of the results of the Dual System Education implementation, by looking at indicators of relevance according to (Wayong, 2010) as follows:

1. The waiting period for graduates to obtain jobs that are relevant to their education is relatively short

2. The level of graduate participation in industry is high or the percentage of graduates absorbed in partner institutions and companies is high

3. Graduates work in accordance with the program or area of expertise being educated.

Turning to current global Vocational Education and Training trends, (McGrath, 2012) summarizes this in what he calls the international dual system education tool kit. He identified five main tools:

1. Systemic governance reforms are intended to make Vocational Education and Training more relevant and responsive

2. Qualification framework

3. Quality assurance system

4. A new funding mechanism that signals a shift from public provider block funding

5. Autonomy managed for public providersintroducing a new governance structure designed to give a greater voice to stakeholders (especially industry).

Dual System Education is a concept of direct training for students in the world of work to implement competencies acquired during learning activities and also as a productoriented marketing concept, this concept that customers in this case the industrial world will see firsthand and choose from the expected quality, best performance and innovative. For Dual System Education to be relevant and in line with the needs of the job market, the school needs to:

1. Understand the industrial work culture that is packaged in learning patterns,

2. Introducing schools with expertise programs that exist in the world of work (industry),

3. Promoting by distributing brochures to the world of work that contains the competencies students have.

Invite industry and institutions involved in the dialogue to inform the program and as a bridge for the implementation of internship and recruitment. The existence of a 4-year Vocational High School has different features and characteristics from the dual management system of education in Germany and Latvia. In fact there are many different models in the Dual System of 3 and 4 year vocational high schools, both the time of implementation, placement and competence. The implementation of dual system education in Indonesia refers to the concept of Link and Match and has become a starting point in determining the vocational education system in Indonesia with the dual system education model adopted. Stating that the interrelation between the school and the world of work which is the concept of the demand link and compatibility between the school world and the world of work absolutely requires a partnership between the two poles. This model was adopted from the vocational education system in Germany, where education is financed part time at school and mostly in industry.

Viewed from the perspective of the development of learning needs and accessibility, so that the dual system education in Vocational Schools has relevance to the business / industry world, at least three main dimensions are a challenge for Vocational Schools, both in regional and national contexts, including:

1. Implementation of education and training programs must focus on utilizing the potential of local resources, while optimizing intensive collaboration with partner institutions 
2. The implementation of the curriculum must be based on a more flexible approach in accordance with development trends and technological advances so that the competencies acquired by students during and after participating in the training program, have a high adaptability

The education and training program must be fully oriented (mastery learning) by involving the active and participatory role of education stakeholders, including optimizing the role of the Regional Government to formulate a mapping of labor competencies in the region as input for vocational high schools in the implementation of education and training sustainable.

In contrast to opinions (Valentina Di Stasioa, 2015) linking theoretical perspectives with educational system institutions and labor market coordination. Empirical results show that education is more likely to function as a position item in countries with a weakly developing vocational education system, where individuals have an incentive to obtain a higher level of education to stay ahead of the workforce queue. However, no convincing support was found for the relationship between wage coordination and returns to too high years of education.

The role of the Regional Government is also very necessary, considering that now regional autonomy, the political will of the local government in order to support the quality of dual system education becomes very necessary, where the local government plays its role as a mediator in making a Memorandum of Understanding between the School and the industrial world and even emphasizes the industrial world. in order to support dual system education activities. Efforts to maintain Vocational School can answer the demands of the community's needs, in this case Vocational School must be able to carry out its roles and functions properly.

In carrying out these roles and functions, education and training in vocational high schools need to pay attention to the principles of vocational education stated according to
(Fachrudin, 2012) that for the management of teaching and learning activities in this dual system of education there are some basic principles, namely:

1. There is a link between what is done at school and what is done at the partner institution as a whole,

2. The practice of expertise in a partner institution is a whole, meaningful and valueladen learning process for achieving graduate competence,

3 . There is continuity of the learning process with the appropriate time in achieving the required level of competence, and

4. Process oriented aside from being product oriented in achieving optimal graduate competencies.

Based on the results of research conducted by (Azzukhruf, 2017) shows that the implementation of dual system education in SMK N 1 Depok has been effective with a percentage of $79 \%$ implementation. Likewise with research conducted by (Sukirno, 2016) at SMK N 1 Klaten has also been effective with a percentage of $80.8 \%$ implementation. Then the results of research conducted by (Wy Trisna Mirah Yanti, 2013) at SMK N 5 Denpasar also showed that the implementation of dual system education was effective with a percentage of $78.9 \%$ implementation. Based on these results, it can be seen that the implementation of dual system education has been effective. This shows that the implementation of dual system education is in sync with the world of work. Then the research (Handa Erwani, 2014) shows that the lack of collaboration between Sintang $\mathrm{N} 1$ Vocational School with the business world and the industrial world so that the graduates produced do not all meet the needs when they enter the workforce.

According to (_, 2015) in Austria, Denmark, Germany, and Switzerland, Vocational Education and Training double accommodates between $40 \%$ (Austria) and $80 \%$ (Switzerland) of all school graduates. Dual System Education in these four countries share the following four main institutional elements: 
1. High level of formalization: They provide centrally accredited job qualification training, and training content is continually adjusted to meet the changing needs of the labor market.

2. Strong involvement of social partners: Representative advisory boards assist in developing and maintaining curriculum at the government and federal levels. The regional trade or work committee, or a combination of both, carries out implementation and monitoring.

3. Vocational schools provide a part of apprenticeship-based kirikulum: Includes general and occupational special education. The government bears the costs of training in schools.

4. Companies must meet certain technical standards: Training companies will not get accreditation if the standards are not met. Offering an internship is optional for companies, but those who choose to offer it follow standard application procedures to match the company with the trainees. Training companies bear the costs of training within the company.

Based on research (Amiruddin, 2016) it can be seen that the aspects of learning, behavior, and results in the application of dual education systems in 4-year SMKs are the effective value of a percentage greater than $50 \%$. Meanwhile, the reaction and results in the application of the dual education system in 3-year SMKs were not effective because the percentage value of effective contributions was less than $50 \%$, the only aspect of learning and effective behavior. So from this result it can be concluded that the 4 year SMK is more synchronous with the work needs in a company compared to the 3 year SMK.

Research (Hanushek, 2012) shows that vocational education seems to have several advantages to help young people enter the company smoothly. So, for example, the German apprenticeship system seems to be very successful. But a nuanced view of the benefits and costs is needed.
A successful vocational training system cannot ignore the development of strong cognitive skills in individuals. Here Germany is also a model, because those on the vocational track also get strong classroom teaching in basic mathematics, science, and language skills.

Furthermore, a successful vocational training system must consider whether trained workers have enough flexibility to adapt to various technologies. This is especially true in fastgrowing economies where individual industries change markedly over time and where the composition of companies in the economy also changes. The need for such flexibility emphasizes the need for a way to provide lifelong learning.

The highly developed German Dual System education may indeed be a model for other countries, but special lessons cannot be lost: vocational skills must be complemented by strong academic skills. And even Germany has to overcome the problem of the work life cycle: high growth and rapid technological change requires ways to ensure the continued work of people with specific vocational skills throughout the entire life cycle.

\section{CONCLUSION/RECOMENDATION}

Dual System Education is a concept of direct training for students in the world of work to implement competencies acquired during learning activities and also as a productoriented marketing concept, this concept that customers in this case the industrial world will see firsthand and choose from the expected quality, best performance and innovative. Vocational Schools need to pay attention to the achievement of the results of the Dual System Education implementation, by looking at indicators of relevance such as the following: 1. the waiting period for graduates to obtain jobs that are relevant to their education is relatively short 2 . The level of graduate participation in industry is high or the percentage of graduates absorbed in partner institutions and companies high. 3. Graduates work in accordance with the program or area of expertise being educated. Thus the success of the Dual System Education program in 
vocational schools will be seen. The implementation of PSG in Indonesia refers to the concept of Link and Match and has become a starting point in determining the vocational education system in Indonesia with the dual system of education model adopted. Stating that the interrelation between the school and the world of work which is the concept of the demand link and compatibility between the school world and the world of work absolutely requires a partnership between the two poles.

\section{REFERENCES}

(2015). A Road Map to Vocational Education and Training in Industrialized Country. Sage.

Amiruddin, D. K. (2016). The Effectiveness Dual System Education Program at 3 and 4 Year Vocational High School on Improving Mechanical Engineering Student Achievement. Proceedings of the International Mechanical Engineering and Engineering Education Conferences, 5.

Azzukhruf, I. D. (2017). Efektivitas Pendidikan Sistem Ganda (PSG) pada Dunia Usaha Dunia Industri (DUDI) Bidang Keahlian Akutansi SMK Negeri 1 Depok Sleman. Yogyakarta: UNY.

Chabbott, C. (2003). Constructing education for development. International Organizations and Education for All. New York: Routledge.

Djati, S. I. (2001). Menuju Masyarakat Belajar, Menggagas Paradigma Pendidikan. Jakarta : Parmadina.

Djojonegoro, W. (2010). Pengembangan Sumberdaya Manusia Melalui Sekolah Menengah Kejuruan. Jakarta: Balai Pustaka.

Fachrudin. (2012). Implementasi Manajemen Hubungan Sekolah dengan Masyarakat dalam Pendidikan Sistem Ganda di SMTI Yogyakarta dan SMk N 4 Yogyakarta. Yogyakarta: UNY.

Gelisi, Y. (2016). Vocational Education Systems in Turkey and the World: new trends and problem. International Journal on New Trends in Education and Their Implications.

Geneva, V. G. (2000). Managing Vocational Training System: Handbook for Senior Administrators. Switzerland: International Labour Officer.

Handa Erwani, Y. S. (2014). Evaluasi Pendidikan Sistem Ganda (PSG) pada Sekolah Menengah Kejuruan
Negeri 1 Sintang. Jurnal Pendidikan dan Pembelajaran Khatulistiwa.

Hanushek, E. A. (2012). Dual Education: Europe's Secret Recipe? CESifo Forum, pp. 29-32.

Heyneman, S. P. (2003). The history and problems in the making of education policy at the World Bank 1960-2000. International Journal of Educational Development, 315-337.

Listiana. (2012). Analisis Pelaksanaan Program Sistem Ganda (PSG) dalam Mempersiapkan Siswa Memasuki Dunia Kerja (Studi Kasus di SMK 5 Pancasila Wonogiri Program Keahlian Administrasi Perkantoran Tahun Diklat 2011/2012. Surakarta: UNS.

McGrath, S. (2012). Building New Spproaches to Thinking about Vocational Education and Training and Development: Policy, Theory and Evidence. International Journal of Educational Development, 619-622.

Soesilowati, E. S. (2009). Link and Match Dunia Pendidikan dan Industri dalam Meningkatkan Daya Saing Tenaga Kerja dan Industri. Jakarta: LIPI Press.

Sukirno, A. I. (2016). Efektivitas Program Pendidikan Sistem Ganda (PSG) pada Dunia Usaha dan Dunia Industri Bidang Keahlian Akuntansi di SMK Negeri 1 Klaten. Jurnal Kajian Pendidikan Akuntansi Indonesia.

Tikly, L. (2013). Reconceptualizing TVET and development: a human capability and social justice approach. In Revisiting global trends in TVET: Reflections on theory and practice (pp. 140). Bonn: UNESCO-UNEVOC.

Valentina Di Stasioa, T. B. (2015). What makes education positional? Institutions, overeducation andthe competition for jobs. Elsevier Ltd., 53-63. doi:http://dx.doi.org/10.1016/j.rssm.2015.09.005

Wayong, A. D. (2010). Relevansi Pendidikan Sistem Ganda (PSG) pada Sekolah Kejuruan dengan Kebutuhan Dunia. Aptekindo.

Wy Trisna Mirah Yanti, M. Y. (2013). Studi Evaluasi Pelaksanaan Pendidikan Sistem Ganda pada Siswa Jurusan Akomodasi Perhotelan di SMK Negeri 5 Denpasar. Jurnal Administrasi Pendidikan Indonesia, 4, 383. doi: https://doi.org/10.23887/japi.v4i1.643 